\title{
Realising Aerobic Rice Potential in India - An Integrated Weed Management Perspective
}

\author{
Chandu Lal Thakur $^{1 *}$, G.K. Shrivastava ${ }^{1}$, B. Sreedevi ${ }^{2}$ and A.K. Thakur ${ }^{1}$ \\ ${ }^{1}$ Department of Agronomy, Indira Gandhi Krishi Vishvavidhayalaya, Krishaknagar, Raipur \\ (C.G.), 492012, India \\ ${ }^{2}$ Agronomy Section, ICAR-Indian Institute of Rice Research, Rajendranagar, Hyderabad \\ (T.S.), 500030, India \\ *Corresponding author
}

Keywords

Aerobic rice, Drydirect seeded, Preemergence herbicide, Post-emergence herbicide, Weed management

Article Info

Accepted:

07 January 2018

Available Online:

10 February 2018

\section{A B S T R A C T}

Aerobic rice is a new way of cultivating rice that requires less water than lowland rice. Direct sown aerobic rice suffers more due to weed menace as the weeds and rice compete for growth factors together. Achieving higher rice grain yields under aerobic conditions requires better weed management practices. Hence, the aerobic rice should be focused primarily on efficient weed management to make aerobic rice cultivation more efficient in terms of returns on farmer investments and use of water resources. Most upland and aerobic rice growers in Asia manually weed their crops two or three times per season. Both pre- and post-emergence herbicides can be used in aerobic rice fields; however they are effective only if properly used. The application of pre-emergence herbicide like pendimethalin, azimsulfuron, pyrazosulfuron and penoxsulam play significant role in controlling weeds. Similarly, post-emergence bispyribac-Na herbicide also considered to be an alternative/ supplement to hand weeding. There is a need to develop sustainable weed management strategies that will give rice a competitive advantage over weeds. The use of herbicides along with appropriate timing, rotation, and combination needs to be integrated with other cultural approaches which ultimately result into higher productivity in aerobic rice.

\section{Introduction}

Rice is the world's most important food and more than half of the world's population depends on rice for food, calories and protein, especially in developing countries. Almost 90 per cent area and production of the world's rice accounted and consumed in Asia. Rice is predominantly grown by transplanting in puddled soil with continuous flooding which provides multiple benefits to rice including reduction in weed population and percolation losses helping in increased availability of nutrients to crop (Sanches, 1973). However, it deteriorates soil physical properties which ultimately affect the growth and productivity of succeeding crops adversely. The increasing cost of labour threatens the sustainability of transplanted rice within the rice-based cropping system. Direct-seeding is cost 
effective, can save water through rice crop establishment and allows early sowing of wheat (Ladha et al., 2003). All these factors have increased the interest of farmers to shift from the conventional practice of puddled transplanting (TPR) to direct seeded rice (DSR) especially dry DSR. Direct seeded rice (DSR) is a cost effective rice establishment method where dry seed is drilled into the nonpuddled soil. This provides opportunities of saving irrigation water by $12-35 \%$, labour up to $60 \%$ and provides higher net returns with similar or slightly lower yield of rice (Kumar and Ladha, 2011). Despite multiple benefits of dry DSR, weed control remains one of the major challenges for its success in South Asia (Singh et al., 2008). Weed control is more difficult in dry-DSR than CT-TPR (Conventional puddle transplanting) because of simultaneously emerging rice seedlings with weeds in dry-DSR which are less competitive than 30-35 days old rice seedlings use in CT- TPR. Initial flooding used in CTTPR is also effective for weed control but it is not same in dry-DSR (Rao et al., 2007). Weeds caused yield loss in direct seeded rice ranging from 14-93\% where as in transplanted rice it is $17-47 \%$ (Ranjit, 2007). Since the concept of aerobic rice is new growing rice under aerobic conditions on raised beds or flat land would require suitable, effective and economic weed-control methods where development of new improved herbicides for aerobic dry-seeded rice is also needed (Belder et al., 2005). Farmers in many rice growing areas are likely to have only limited availability of irrigation water and in the future it is predicted that in Asia, 17 million ha of irrigated rice areas may experience "Physical water Scarcity" and 22 million ha may have "economic water Scarcity" by 2025 (Bouman and Tuong, 2001). Water scarcity threatens the sustainability of irrigated rice ecosystems since it may no longer be feasible for farmers to undertake wet cultivation. Most upland and aerobic rice growers in Asia manually weed their crops two or three times per season, investing upto 190 person days $\mathrm{ha}^{-1}$ in hand weeding (Roder, 2001). It is very environment-friendly but it is tedious, time consuming and highly labor intensive and expensive. In addition, during peak period, the availability of labor is becoming a serious problem by time. Both pre- and postemergence herbicides can be used in aerobic rice fields; however they are effective only if properly used (Singh et al., 2006a). The application of pre-emergence herbicide like pendimethalin (Bhurer et al., 2013), azimsulfuron (Singh et al., 2009), pyrazosulfuron, penoxsulam (Chauhan and Seth, 2013) and post emergence bispyribac-Na (Khaliq et al., 2012) plays significant role in controlling weeds. To the best of our knowledge, a very few experiments were carried out in this line with a view to evaluating the efficacy of herbicides under field conditions for selecting suitable herbicides and their combinations for sustainable weed control in aerobic rice.

\section{Weed flora composition in aerobic rice}

Precise information regarding the prevalent weed flora is highly important for formulating the most suitable weed management programs. The prevalence, germination, and growth of weeds are largely influenced by rice cultivation methods. A number of weed species have been reported to infest aerobic rice systems (Table 1). Moreover, a more difficult-to-control and complex weed flora can be found in rice grown using this method compared with the conventional method (Mahajan et al., 2009). Most of the rice growing areas are located either in subtropical or tropical zones, and hence, are characterized with environmental conditions such as luminosity and high humidity. These weather conditions heavily favour profuse weed growth. Further, the soil in aerobic rice 
systems is kept moist instead of flooded that favours higher weed germination. Hence, high weed germination as well as weed growth is supported by the climatic conditions under which aerobic rice is grown. Interestingly, the weed species of conventionally flooded rice (CFR) and aerobic rice systems vary certainly (Figure 1). For example, Trianthema portulacastrum L. is rarely found in CFR but it grows abundantly and rapidly in growthconducive aerobic rice systems (Jabran et al., 2012).

\section{Influence of herbicides on yield of crop}

\section{Pre - emergence herbicides}

In aerobic rice, the grain yield could be increased by 5.5 to 10.4 times and the straw yield by 2.0 to 3.4 times when weeds were effectively controlled (Singh et al., 2005). Oxadiargyl @ $160 \mathrm{~g} \mathrm{ha}$ (Ahmed and Chauhan, 2015), pretilachlor @ $0.75 \mathrm{~kg} \mathrm{ha}^{-1}$ or pendimethalin $1.00 \mathrm{~kg} \mathrm{ha}^{-1}$ (Singh et al., 2013), oxyflourfen @ $0.125 \quad \mathrm{~kg} \mathrm{ha}^{-1}$ (Kathiresan and Manoharen, 2002) and pyrazosulfuron ethyl @ $25 \mathrm{~g} \mathrm{ha}^{-1}$ (Saha, 2006) are found to be effective in controlling weeds and resulted higher rice grain yield.

\section{Post - emergence herbicides}

Post-emergence application of bispyribac-Na $80 \mathrm{~g} \mathrm{ha}^{-1}$ (Rawat et al., 2012), fenoxaprop-pethyl @ $75 \mathrm{~g} \mathrm{ha}^{-1}$ or cyhalofop butyl @ $100 \mathrm{~g}$ $\mathrm{ha}^{-1}$ at 15 DAS (Sasikala et al., 2014) and mixture of fenoxaprop + ethoxysulfuron at 30 DAS ${ }^{36}$ recorded maximum grain yield at various locations.

\section{Sequential application and mixture of herbicides}

Integration of pre-emergence application of pendimethalin $0.75 \mathrm{~kg} \mathrm{ha}^{-1}$ or oxadiargyl 0.90 $\mathrm{g} \mathrm{ha}{ }^{-1}$ with post-emergence application of
bispyribac-Na $25 \mathrm{~kg} \mathrm{ha}^{-1}$, azimsulfuron $20 \mathrm{~g}$ $\mathrm{ha}^{-1}$ and 2,4-D $0.5 \mathrm{~kg} \mathrm{ha}^{-1}$ resulted in significant increase in grain yield as compared to pendimethalin $0.75 \mathrm{~kg} \mathrm{ha}^{-1}$ alone (Walia et al., 2012; Sreedevi et al., 2016).

The combined application of pendimethalin or clomazone as pre-emergence fb bispyribacsodium as post-emergence or tank-mixture of clomazone + bispyribac sodium effectively controlled weeds and increased the yield (Ghosh et al., 2016).

A compiled report of All India Coordinated Rice Improvement Project revealed that pre + post-emergence application of herbicide was effective in controlling weeds (Table 2) and significantly increased rice yield compared to unweeded and comparable with need based hand weeding (Table 3).

\section{Effect of herbicide toxicity on crop}

Phytotoxicity is the capacity of a compound (such as a plant protection product) to cause temporary or long-lasting damage to plants. Phytotoxicity effects may be observed on the crop at emergence or during its growth or may be expressed at harvest.

They may be temporary or lasting. The symptoms may affect the whole plant or any part of the plant (roots, shoots, leaves, flowers) and may be accurately described by figure 2. In practice, in trials for efficacy evaluation of plant protection products, it is unlikely that the most striking symptoms described here will be observed very frequently, for products causing such phytotoxicity would be unlikely to reach the stage of field testing.

Accordingly, the symptoms of phytotoxicity will often be inconspicuous, and the researchers will be looking for only a slight expression of the symptoms outlined below: 
Fig.1 Major weed flora in aerobic rice

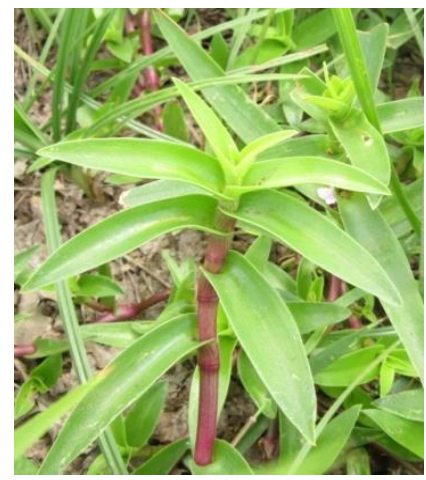

Commelina diffusa

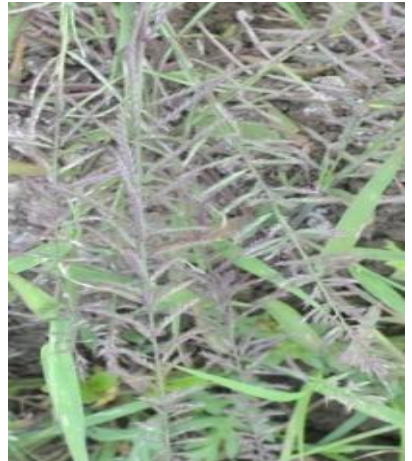

Dinebra retroflexa

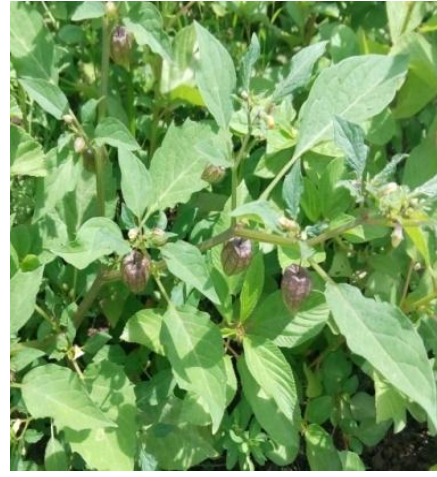

Physalis minima

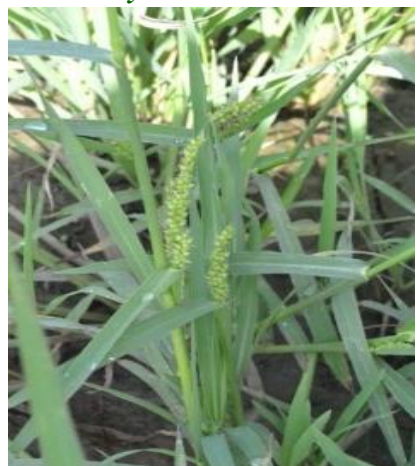

Echinochloa colonum

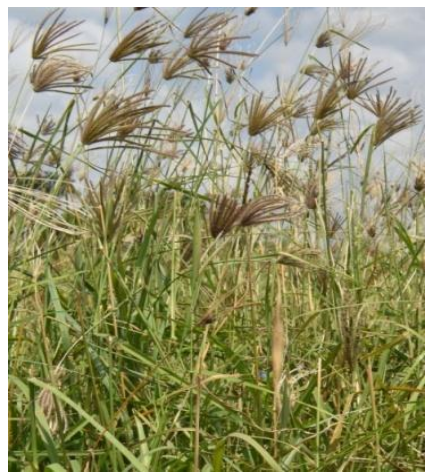

Chloris barbata

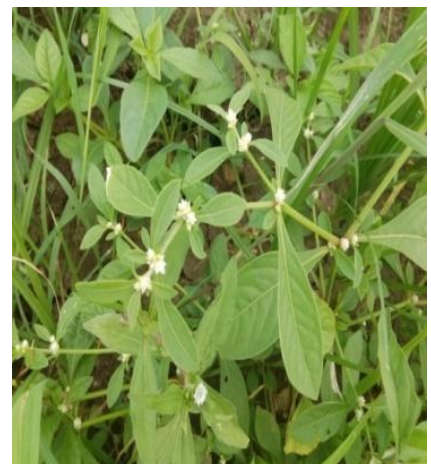

Alternanthera sessilis

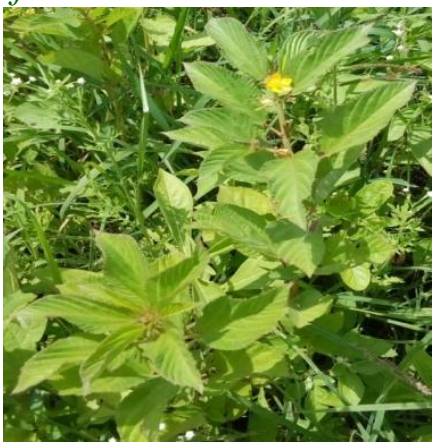

Corchorus olitorius

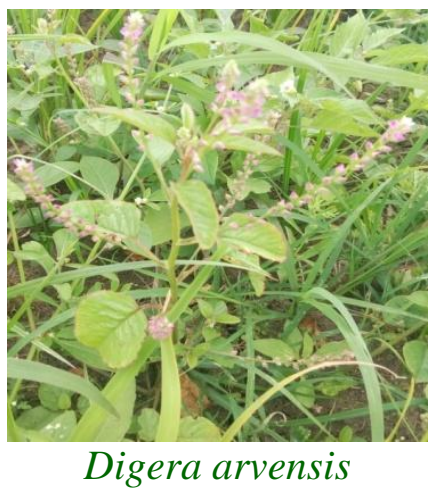

Fig.2 Herbicide phytotoxicity symptoms in aerobic rice
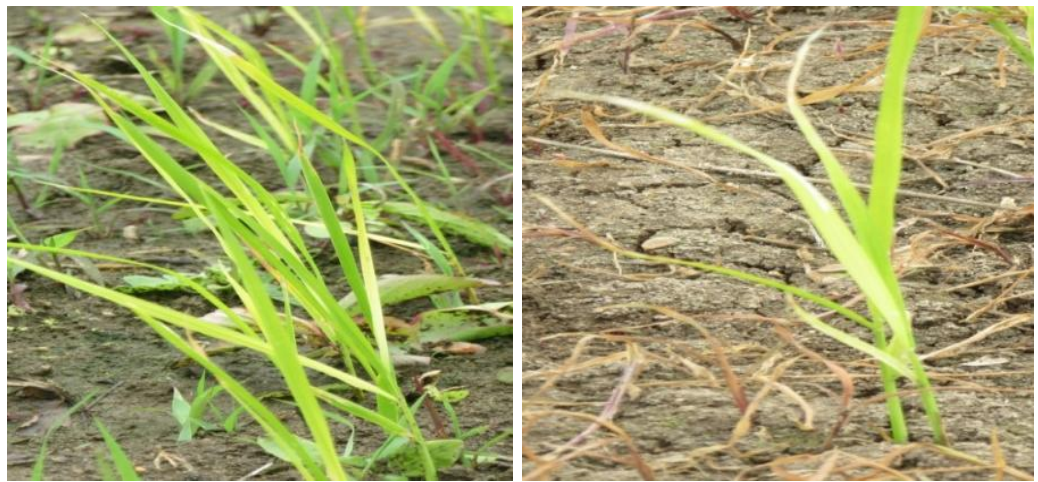

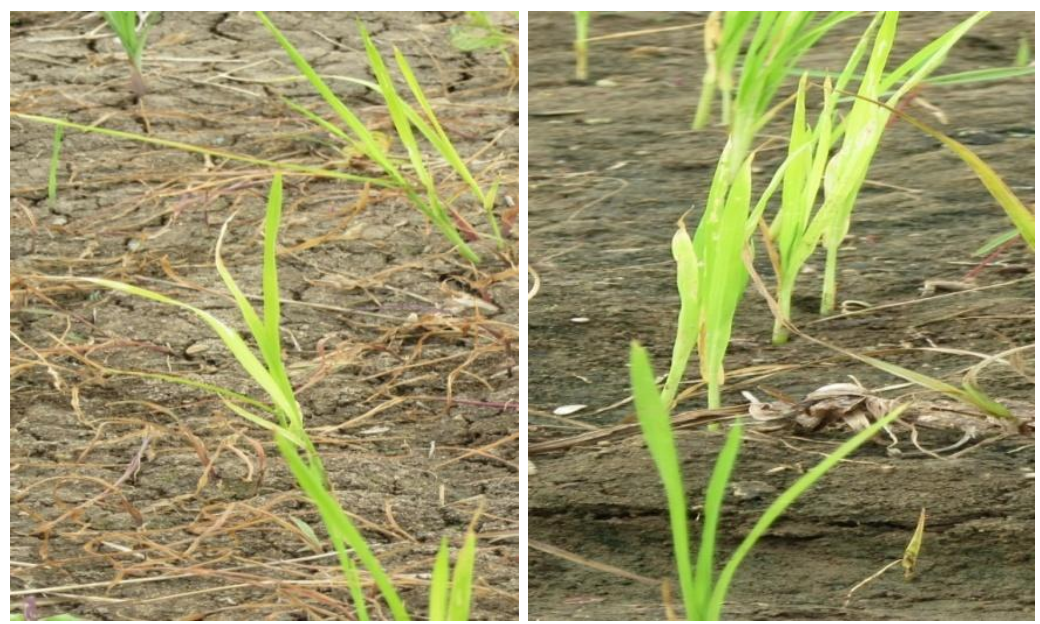

Table.1 Common weed flora of the aerobic rice

\begin{tabular}{|c|c|c|}
\hline S.N. & Botanical Name & Family \\
\hline I. & Grasses & \\
\hline 1. & Echinochloa colonum & Poaceae \\
\hline 2. & Echinochloa crusgalli & Poaceae \\
\hline 3. & Digitaria sanguinalis & Poaceae \\
\hline 4. & Chloris barbata & Poaceae \\
\hline 5. & Dinebra retroflexa & Poaceae \\
\hline 6. & Eleusine indica & Poaceae \\
\hline 7. & Ischaemum rugosum & Poaceae \\
\hline II. & Sedges & \\
\hline 1. & Cyperus rotundus & Cyperaceae \\
\hline 2. & Cyperus iria & Cyperaceae \\
\hline 3. & Cyperus difformis & Cyperaceae \\
\hline III. & Broad leaved weeds & \\
\hline 1. & Corchorus olitorius & Tiliaceae \\
\hline 2. & Digera arvensis & Amaranthaceae \\
\hline 3. & Phyllanthus niruri & Phyllanthaceae \\
\hline 4. & Trianthema portulacastrum L. & \\
\hline 5. & Acalypha indica & Euphorbiaceae \\
\hline 6. & Alternanthera sessilis & Amaranthaceae \\
\hline 7. & Commelina benghalensis & Commelinaceae \\
\hline 8. & Commelina diffusa & Commelinaceae \\
\hline 9. & Merremia emarginata & Convolvulaceae \\
\hline 10 & Physalis minima & Solanaceae \\
\hline
\end{tabular}


Table. 2 Suitable pre, post and pre + post-emergence herbicides to control weeds in aerobic rice

\begin{tabular}{|c|c|c|c|c|c|c|}
\hline \multirow[t]{2}{*}{ S.N. } & \multicolumn{2}{|l|}{ Pre-emergence } & \multicolumn{2}{|l|}{ Post-emergence } & \multicolumn{2}{|l|}{ Pre + Post emergence } \\
\hline & Dose of herbicides & References & Dose of herbicides & References & Dose of herbicides & References \\
\hline 1 & $\begin{array}{l}\text { Pyrazosulfuron ethyl } \\
\text { @ } 20 \text { to } 25 \mathrm{~g} \mathrm{ha}^{-1}\end{array}$ & 17 & $\begin{array}{l}\text { Bispyribac-Na } 10 \% \\
\text { SC @ } 40 \mathrm{~g} \mathrm{ha}^{-1}\end{array}$ & 22 & $\begin{array}{l}\text { Cyhalofop-butyl + } \\
\text { Bensulfuron fb } \\
\text { Bentazon/MCPA }\end{array}$ & 26 \\
\hline 2 & $\begin{array}{l}\text { Pretilachlor@ } \\
0.75 \mathrm{~kg} \mathrm{ha}^{-1}\end{array}$ & 18 & $\begin{array}{l}\text { Cyhalofop-butyl @ } \\
\text { (60 to } 150 \mathrm{~g} \mathrm{ha}^{-1}\end{array}$ & 4 & $\begin{array}{l}\text { Pendimethalin } \mathrm{fb} \\
\text { Azimsulfuron }\end{array}$ & 27 \\
\hline 3 & $\begin{array}{l}\text { Oxyfluorfen } 23.5 \% \text { EC @ } \\
100 \text { to } 400 \mathrm{~g} \mathrm{ha}^{-1}\end{array}$ & 19 & $\begin{array}{l}\text { Azimsulfuron@ } \\
25 \text { to } 30 \mathrm{~g} \mathrm{ha}^{-1}\end{array}$ & 23 & $\begin{array}{l}\text { Oxadiazon } \mathrm{fb} \text { Bispyribac- } \\
\text { sodium @ } 45 \mathrm{~g} \mathrm{ha}^{-1} \mathrm{fb} 2,4-\mathrm{D}\end{array}$ & 28 \\
\hline 4 & $\begin{array}{l}\text { Pendimethalin@ (1-1.5 } \\
\text { g ha-1) and oxadiargyl @ } \\
\left(0.4-0.7 \mathrm{~g} \mathrm{ha}^{-1}\right)\end{array}$ & 20 & $\begin{array}{l}\text { Fenoxaprop-p-ethyl } \\
\text { @ 47-60 g ha-1 }\end{array}$ & 24 & $\begin{array}{l}\text { Pretilachlor@ } 950 \\
\mathrm{~g} \mathrm{ha}^{-1} \mathrm{fb} \text { Azimsulfuron } \\
\text { @ } 35 \mathrm{~g} \mathrm{ha}^{-1}\end{array}$ & 29 \\
\hline 5 & $\begin{array}{l}\text { Pendimethalin @ (1.0 to } \\
\left.2.0 \mathrm{~kg} \mathrm{ha}^{-1}\right) \text { and anilofos } \\
\left(0.4 \text { to } 0.8 \mathrm{~kg} \mathrm{ha}^{-1}\right)\end{array}$ & 21 & $\begin{array}{l}\text { Carfentrazone-ethyl } \\
40 \text { DF @ } 20 \mathrm{~g} \mathrm{ha}^{-1}\end{array}$ & 25 & $\begin{array}{l}\text { Pendimethalin @1 kg } \\
\text { ha }^{-1} f b \text { Bispyribac- } \\
\text { sodium @35 g ha }{ }^{-1}\end{array}$ & 30 \\
\hline
\end{tabular}


Table.3 Comparative performance of various weed management treatments on Yield of aerobic rice

\begin{tabular}{|l|c|c|c|l|l|l|l|}
\hline $\begin{array}{l}\text { Name of } \\
\text { Centres }\end{array}$ & Unweeded & $\begin{array}{l}\text { Need } \\
\text { based } \\
\text { hand } \\
\text { weeding }\end{array}$ & $\begin{array}{l}\text { Pre-+Post- } \\
\text { emergence } \\
\text { herbicide }\end{array}$ & $\begin{array}{l}\text { Name of } \\
\text { Centres }\end{array}$ & Unweeded & $\begin{array}{l}\text { Need } \\
\text { based } \\
\text { hand } \\
\text { weeding }\end{array}$ & $\begin{array}{l}\text { Pre-+Post- } \\
\text { emergence } \\
\text { herbicide }\end{array}$ \\
\hline Chakcha & 3.24 & 5.99 & 5.78 & Bankura & 1.26 & 4.2 & 3.84 \\
\hline Coimbatore & 1.73 & 3.73 & 3.52 & Dharwad & 0.65 & 6.92 & 6.14 \\
\hline Dharwad & 0 & 6.23 & 6.22 & Hathwara & 1.09 & 3.26 & 3.08 \\
\hline Hathwara & 1.25 & 4.52 & 4.38 & Jagdalpur & 1.01 & 1.58 & 3.40 \\
\hline Kota & 1.75 & 5.23 & 4.73 & Patna-ARI & 1.52 & 4.6 & 4.33 \\
\hline Patna-ARI & 1.06 & 5.83 & 5.25 & Pusa & 1.72 & 3.78 & 3.61 \\
\hline Pusa & 1.81 & 4.35 & 4.17 & Varanasi & 1.30 & 3.70 & 3.68 \\
\hline Vadgaon & 1.60 & 5.58 & 4.91 & Vadgaon & 1.53 & 5.4 & 5.33 \\
\hline
\end{tabular}

Pre (Pendimethalin 30 EC @ $1 \mathrm{~kg} \mathrm{ha}^{-1}$ (3-4 DAS) + Post (Bispyribac- sodium (10\% SC) @ $35 \mathrm{~g} \mathrm{ha}^{-1}(15-20 \mathrm{DAS})$ (DRR Progress report, 2012-13) ${ }^{40}$

Table.4 Crop phytotoxicity rating using 0 to 10 point scale

\begin{tabular}{|c|l|l|}
\hline Rating & Crop phytotoxicity symptoms & Remarks \\
\hline $\mathbf{0}$ & No injury, normal & None \\
\hline $\mathbf{1}$ & Slight stunting injury or discoloration & \\
\hline $\mathbf{2}$ & Some stand loss, stunting or discoloration & Slight \\
\hline $\mathbf{3}$ & Injury more pronounced but not persistent & \\
\hline $\mathbf{4}$ & Moderate injury, recovery possible & \\
\hline $\mathbf{5}$ & Injury more persistent, recovery possible & Moderate \\
\hline $\mathbf{6}$ & Near severe injury, no recovery possible & \\
\hline $\mathbf{7}$ & Sever injury, stand loss & \\
\hline $\mathbf{8}$ & Almost destroyed, a few plants surviving & Severe \\
\hline $\mathbf{9}$ & Very few plants alive & Complete \\
\hline 10 & Complete destruction & (Source: Ra0, 1986) \\
\hline
\end{tabular}

Table.5 Effect of weed management practices on benefit cost ratio of aerobic rice

\begin{tabular}{|c|c|c|}
\hline Net return (Rs/ ha) & B:C ratio & References \\
\hline $\mathbf{2 1 , 9 5 4}$ & 1.30 & 55 \\
\hline $\mathbf{2 8 , 2 8 1}$ & 2.25 & 56 \\
\hline $\mathbf{2 1 , 0 1 9}$ & 2.15 & 14 \\
\hline $\mathbf{1 0 , 9 4 0}$ & 1.77 & 57 \\
\hline $\mathbf{9 , 4 5 9}$ & 1.98 & 58 \\
\hline $\mathbf{5 7 , 0 6 3}$ & 2.3 & 59 \\
\hline
\end{tabular}




\section{Delay in emergence}

Thinning

Number of seedlings

Number of panicles

\section{Delay}

In reaching various growth stages

In emergence of inflorescences

In ripening of grain

\section{Inhibition}

Reduction in number of tillers

\section{Discolouration of leaves}

Paler or darker green

White leaves

\section{Necrosis of leaves}

All kinds of deformations of the leaves, the stems or the inflorescences

\section{May be noted}

Curling or other deformations of the leaves

Alteration in habit

Length or deformations of the stem

Deformations of the inflorescences (e.g. Double or forked ears, additional spikelets)

Failure of normal booting and inflorescence emergence

\section{Effects on yield}

Total grain yield in $\mathrm{kg} \mathrm{ha}^{-1}$

Grain weight per hill
1000 grain weight

Seed grading

Further crop phytotoxicity can be rated in the following manner (Table 4).

The application timing of pre-emergence herbicides in aerobic rice needs to be adjusted so as to minimize the damage to rice crop (Matloob et al., 2015). The higher grain yield (1805 kg ha $\mathrm{kg}^{-1}$ was obtained with the application of Mon-46992@ 2.5 ha $^{-1} 12-14$ DAS. Crop phytotoxicity was observed at 10 days after spraying with Mon-46992 applied either at 3.75 or 5.0 liter ha $^{-1}$ of herbicide. Toxic effects were not observed after 20 to 30 days of the treatment. Weed control was better with the higher doses of Mon 46992 irrespective of the time of spray (Raikar et al., 2009). A high rate of oxadiargyl applied at $150 \mathrm{~g} \mathrm{ha}^{-1}$ caused seedling mortality in rice in anaerobic conditions but not in aerobic conditions (Gitsopoulos and Froud-Williams, 2004). The increased rate of bispyribac- $\mathrm{Na}$ controlled weeds more effectively than the recommended rate; however, grain yield was slightly decreased, which could be due to the phytotoxicity of the increased rate of bispyribac-sodium (Chauhan and Johnson, 2011). Pre-emergence oxyfluorfen and postemergence 2,4-D on 30 DAS showed phytotoxicity rating of 5 at 10 DAS and 4 at 20 DAS and no toxicity before harvest (Kathiresan and Manoharen, 2002). There was no phytotoxic effect of bispyribacsodium at any of the doses $(15,20$ and $25 \mathrm{~g}$ $\mathrm{ha}^{-1}$ ) on direct seeded rice crop (Singh et al., 2014). Pendimethalin rates higher than the recommended rate $\left(800 \mathrm{~g} \mathrm{ha}^{-1}\right)$ effectively controlled weeds but resulted in lower crop yield due to phytotoxicity (Ahmed and Chauhan, 2015). An increase in bispyribacsodium rate from 30 to $50 \mathrm{~g} \mathrm{ha}^{-1}$ increased weed control efficiency by 7\%; however, it decreased plant density and biomass by $19 \%$ 
and 14\%, respectively (Rao and Ratnam, 2010). Therefore, the application of an appropriate herbicide rate is very important in achieving adequate weed control and in reducing crop phytotoxicity (Harding et al., 2012).

\section{Integrated weed management in aerobic rice}

Weed management must aim at reducing the weed population to a level at which weeds occurrence has no effect on farmer's economic and ecological interests. By using different appropriate management practices against weeds, farmers have more options for controlling weeds, thereby reducing the possibility of escapes and weed adaptation to any single weed management tactic.

Integrated weed management (IWM) is a science-based decision-making process that coordinates the use of environmental information, weed biology and ecology, and all available technologies to control weeds by the most economical means, while posing the least possible risk to people and the environment. IWM through application of pre-emergence application of pendimethalin 1 $\mathrm{kg} \mathrm{ha}^{-1}$ followed by 2,4-D $1 \mathrm{~kg} \mathrm{ha}^{-1}$ at 25 DAS followed by HW 45 days after sowing resulted best alternative for manual hand weeding practices higher yield, higher net return per unit investment and controlling weeds effectively in dry direct seeded rice (Bhurer et al., 2013).

Higher weed control efficiency and lower weed index was recorded with Bensulfuron methyl + Pretilachlor (6.6 GR @ 0.06 + 0.60 $\mathrm{kg} \mathrm{ha}^{-1}$; a pre-mix formulation) + one inter cultivation at 40 DAS (Sunil et al., 2010). Pre-emergence application of pendimethalin at $1.0 \mathrm{~kg} \mathrm{ha}^{-1}$ followed by mechanical weeding with single type sweep weeder at 45 DAS followed by single wheel hoe at 45 DAS and both proved more remunerative than HW twice at 25 and 45 days (Chinnusamy et al., 2009). Pre-emergence applications of either butachlor +2 ,4-D $\left(1.5+0.5 \mathrm{~kg} \mathrm{ha}^{-1}\right)$ or thiobencarb +2 , 4-D $\left(1.5+0.5 \mathrm{~kg} \mathrm{ha}^{-1}\right)$ or anilofos + 2, 4-D $\left(0.4+0.5 \mathrm{~kg} \mathrm{ha}^{-1}\right)$ followed by one HW at 25 DAS were effective ways to minimize weed competition and enhance grain yield of direct dry seeded rainfed upland rice (Singh et al., 2006b).

Pre-emergence application of pendimethalin $1.0 \mathrm{~kg} \mathrm{ha}^{-1} \mathrm{fb}$ bispyribac $25 \mathrm{~g} \mathrm{ha}^{-1}+$ readymix chlorimuron + metsulfuron $4 \mathrm{~g} \mathrm{ha}^{-1}$ at 30 DAS $\mathrm{fb}$ one HW at $60 \mathrm{DAS}$, recorded significantly lower weed density, weed biomass and higher WCE of $82 \%$ at 60 DAS (Ganie). Use of pendimethalin $1 \mathrm{~kg} \mathrm{ha}^{-1}$ (pre-emergence) $\mathrm{fb}$ azimsulfuron $35 \mathrm{~g} \mathrm{ha}^{-1}$ at 15-20 DAS + one HW at 40 DAS proved to be most effective in minimizing the weed density, dry weight and weed persistence index (0.08 and 0.04) and in enhancing the weed control efficiency (72.04\% and $76.77 \%$ ) also maximum grain yield, straw yield and biological yield (Singh and Singh, 2014).

Suitable date of sowing and variety are changing with early sowing (5 June - 3 July) showed higher productivity and hybrid showed superior performance than high yielding varieties by manipulating these two factor higher productivity of aerobic rice can be attained with reduced water requirements (Indian institute of rice research progress report of crop production, 2014).

Hybrids and long duration high yielding varieties are found to have better weed suppressing ability and registered lower weed population and biomass during the season (Indian institute of rice research progress report of crop production, 2015). Integrated weed management not only reduce weeds, increase yield but also more profitable (Table 5). 
Future scope of weed management in aerobic rice

\section{Mechanical weed control}

Dry direct seeded rice is grown in rows as well as broadcast. Therefore, mechanical weed control is not very common, as its scope is limited to row-seeded crops. In addition, mechanical weeders require an optimum soilwater condition to work efficiently and effectively. However, mechanical weeding (e.g., using a star weeder, finger weeder, wheel hoe, or cono weeder) in conjunction with pre-emergence herbicide applications can be used as an effective tool in IWM in DSR. Mechanical weeding could be more effective in situations in which continuous rains or dry spells may reduce the effectiveness of post-emergence herbicides. Mechanical weeders can also help to reduce overall herbicide use. However, there is a need to evaluate the labor requirements and economics in relation to chemical control.

\section{Weed-competitive rice genotypes}

The use of weed-competitive genotypes is the key requirement in developing weed management strategies in any crop (Mahajan and Chauhan, 2013). The use of such genotypes might help reduce selection pressure, herbicide use, and labor costs. Weed competitiveness has been attributed to a crop's ability to tolerate and suppress weeds (Jannink et al., 200). Increased crop competitiveness against weeds could lower the cost incurred in weed control by up to 30\% (Sanint et al., 1998). Weed suppression ability of the crop can be judged in terms of a reduction of weed biomass production, while weed tolerance is the ability of a genotype to maintain its yield under weedy conditions. Weed tolerance can be determined only for genotypes with the same weed-suppressing ability and yield potential. A strong weed- suppressing ability does not necessarily mean a high yield advantage if the potential yield is low (Zhao et al., 2006). A competitive genotype might help in limiting the dose of herbicides by suppressing weed emergence and growth. Therefore, the development and use of weed-competitive genotypes in DSR systems would provide a safe and environmentally friendly tool for weed management with less use of herbicides in the agro-ecosystem.

\section{Herbicide-resistant genetically modified rice}

Herbicide resistant (HR) rice technologies have the potential to control a wide range of weeds including grasses, broad-leaved and sedges which cause serious problems in lowland rice, including problematic weeds like Echinochloa spp. and weedy rice (Rodenburg and Demont, 2009). The ability to control problem weed species efficiently makes HR rice an attractive technology and farmers may rapidly adopt it in many cases. Three HR systems have been developed in rice: imidazolinone, glufosinate and glyphosate -resistant varieties (Gealy et al., 2003). Glyphosate and glufosinate are considered as relatively environmentally benign and, as post-emergence herbicides, the application rates can be adjusted to the weed population, and the technology has wider herbicide application time window compared to conventional technologies. Despite the possible advantages of HR options, there are concerns regarding the likelihood of gene flow from HR rice to wild and weedy rice species. In India, $O$. sativa $f$. spontanea is considered as weedy species in cultivated rice. In Eastern India (e.g. Eastern Uttar Pradesh, Bihar, Odisha, Manipur, and West Bengal) and Southern India, wild and weedy relatives are common and gene flow may occur from HR rice to these species (Kumar et al., 2008). The reliance on HR technology 
for effective weed control in rice will depend thus on careful introduction and management.

\section{Exploration of potential bio-agents}

In some developed countries several biocontrol agents have been used successfully in specific situations. In India also few attempts have been made for application of some fungal pathogen and insect bio-control agents over rice weeds. However, very low abundance of these bio-control agents at specific situation has resulted in failure of wider application and commercial success. In lowland rice Ludwigia parviflora was reported to be completely defoliated in lowland transplanted rice by Halticid beetle (Mukhopadhyay and Duary, 1999) indicating its potentiality as a bio-control agent against the weed. The possibilities of such bio-control agents should be explored by identifying natural enemies through auto-ecological studies of major weeds in lowland rice.

\section{Developing allelopathic rice and $\mathrm{C}_{4}$ rice}

Some rice lines or wild rice species have been found to be allelopathic and can inhibit the growth of some weeds like barnyard grass and broad-leaf weeds (Olofsdotter et al., 1995). A number of compounds such as phenolic acids, fatty acids, phenylalkanoic acids, hydroxamic acids, terpenes and indoles have been identified as potential rice allelochemicals. The momilactone $\mathrm{B}$ secreted from rice seedlings appears to be the major contributor to the allelopathic activity of rice crops at least against barnyard grass (Kato-Noguchi, 2013). Similar attempts may be made in India and rice cultivars are to be screened for their allelopathic potentials. Rice scientists are aiming for a second Green Revolution by developing $\mathrm{a}^{\mathrm{C}_{4}}$ rice through traditional breeding or transgenic methods (Gunawardana, 2008). At present rice being a $\mathrm{C}_{3}$ plant is less competitive than $\mathrm{C}_{4}$ weeds like E. crusgalli and C. rotundus. $\mathrm{A}_{4}$ rice will be more competitive against weeds, more efficient in photosynthesis and will yield high even with less water, since water requirement of $\mathrm{C}_{4}$ plants is much lower than that of $\mathrm{C}_{3}$ plants (Baltazar and Johnson, 2013).

Dry direct seeded rice systems are increasing in several Asian countries because of labor and/or water shortages. However, weeds are the most important biological constraint in these production systems. The successful adoption of dry direct seeded rice systems in farmers' fields will mainly depend on the solutions available to manage weeds. Herbicides are a possible solution to manage weeds in Dry direct seeded rice, but the sole use of herbicides cannot provide effective and season long weed control. In addition, a weed control method focusing entirely on herbicides is no longer ecologically sound, economically feasible, and effective against the diverse weed flora in dry-direct seeded rice. Therefore, there is a need to develop sustainable weed management strategies that will give rice a competitive advantage over weeds. The use of herbicides (appropriate timing, rotation, and combination) needs to be integrated with other cultural approaches, such as the use of weed-competitive cultivars, optimum sowing time, the use of stale seedbed practices, the use of a high seeding rate and narrow crop row spacing, appropriate fertilizer and water inputs and their application method/timing, mechanical weeding, etc., to achieve effective, sustainable, and season-long weed control in dry direct seeded rice systems.

\section{References}

Abraham, C.T., Prameela, P. and Laxmi, M.P. Bioefficacy testing of fenoxaprop-p-ethyl against weeds in direct-seeded rice. Indian J. Weed Sci., 2012, 44(2): 92-94.

Ahmed, S. and Chauhan, B.S. Efficacy and phytotoxicity of different rates of 
oxadiargyl and pendimethalin in dryseeded rice (Oryza sativa L.) in Bangladesh. Crop Prot., 2015, 72: 169174.

Anwar, M.P., Juraimi, A.S., Puteh, A., Man, A. and Rahman, M.M. Efficacy, phytotoxicity and economics of different herbicides in aerobic rice. Soil and Plant Sci., 2012, 62: 604-615.

ARWR. 2011. 30 ${ }^{\text {th }}$ Annual Research Workshop on Rice. Crop management. Tamilnadu Rice Research Institute, Aduthurai, TNAU, Coimbatore, 2011, P-15, 45 \& 50.

Baltazar, A.M. and Johnson, D.E. Challenges and problems in managing weeds in rice: present and future solutions, pp.116-125. In: Proceedings of $24^{\text {th }}$ Asian-Pacific Weed Science Society Conference, October 22-25, 2013, Bandung, Indonesia.

Belder P, Bouman, B.A.M., Spiertz, J.H.J., Peng, S., Castaneda, A.R. and Visperas, R.M. Crop performance, nitrogen and water use in flooded and aerobic rice. Plant soil, 2005, 273:167-182.

Bhurer, K.P., Yadav, D.N., Ladha, J.K., Thapa, R.B. and Pandey, K. Effect of integrated weed management practices on performance of dry direct seeded rice (Oryza sativa L.). Agron. J. Nepal, 2013, 3.

Bouman, B.A.M. and Tuong, T.P. Field water management to save water and increase its productivity in irrigated rice. Agric. Water Manage, 2001, 49: 11-30.

Chauhan, B.S. and Johnson, D.E. Row spacing and weed control timing affect yield of aerobic rice. Field Crops Res., 2011, 121: 226-231.

Chauhan, B.S. and Seth, A.B. Weed Management in Mechanized-Sown, ZeroTill Dry Seeded Rice, 2013, http.//dx.doi.org/10.1614/2013, WT-D12-0088.1.

Chauhan, B.S., Ahmed, S. and Awan, T.H. Performance of sequential herbicides in dry-seeded rice in the Philippines. Crop Prot., 2015, 74: 124-130.

Chinnusamy, C., Kalaichelvi, K. and
Prabhakaran, N.K. Effect of mechanical weeding on weeds infestation productivity and profitability of aerobic rice. Indian J. Weed Sci., 2009, 41(1\&2): $38-40$.

Directorate of Rice Research, Progress Report, 2012-13 Vol.3 Crop Production All India Coordinated Rice Improvement Programme (ICAR) Directorate of Rice Research, Rajendranagar, Hyderabad 500030, India.

Ganie, Z.A., Singh, S. and Singh, S. Integrated weed management in dry-seeded rice. Indian J. Weed Sci., 46(2): 172-173.

Gealy, D.R., Mitten, D.H. and Rutger, J.N. Gene flow between red rice (Oryza sativa) and herbicide-resistant rice $(O$. sativa): implications for weed management. Weed Techn, 2003, 17: 627645.

Ghosh, D., Singh, U.P., Ray, K. and Das, A. Weed management through herbicide application in direct-seeded rice and yield modeling by artificial neural network. Spanish J. Agricultural Res., 2016, 14(2): 1003.

Gitsopoulos, T.K. and Froud-Williams, R.J. Effects of oxadiargyl on direct-seeded rice and Echinochloa crusgalli under aerobic and anaerobic conditions. Weed Res., 2004, 44: 329-334.

Gunawardana, D. Supercharging the rice engine. Rice Today, 2008, 7(3): 20-21.

Harding, S.S., Taylor, D.R., Jalloh, A.B., Mahmood, N., Dixon, C.A. and Johnson, S.D. Evaluation of the efficacy of different rates of herbicides on weed growth and grain yield of two rice varieties in two rice ecologies in Sierra Leone. Amer. J. Exper. Agri., 2012, 2: 607-615.

Indian institute of rice research progress report of crop production (Agronomy, Soil Science and Plant Physiology) - 2014 (Vol. 3) All India Coordinate Rice Improvement Program (ICAR), Indian institute of rice research Hyderabad, India, 2015, pp 4.4.

Indian institute of rice research progress report 
of crop production (Agronomy, Soil Science and Plant Physiology) - 2015 (Vol. 3) All India Coordinate Rice Improvement Program (ICAR), Indian institute of rice research Hyderabad, India, 2016, pp 4.199.

Jabran, K., Hussain, M., Farooq, M., Babar, M., Dogan, M.N. and Lee, D.J. Application of bispyribac-sodium provides effective weed control in direct-planted rice on a sandy loam soil. Weed Biol. Manag., 2012, 12, 136e145. http:// dx.doi.org/10. 1111/j.1445-6664.2012.00446.x.

Jannink, J.L., Orf, J.H., Jordan, N.R., Shaw, R.G. Index selection for weedsuppressive ability in soybean. Crop Sci., 2000, 40: 1087-1094.

Kashid, N.V., Barhate, K.K. and Bodake, P.S. Management of weeds in direct-seeded rice. Indian J. Weed Sci., 2015, 47(2): 110-112.

Kathiresan, G. and Manoharen, M.L. Effect of seed rate and methods of weed control on weed growth and yield of direct sown rice. Indian J. Weed Sci., 2002, 47: 212215.

Kato-Noguchi, H. Momilactone plays a crucial role in rice allelopathy, pp. 60-67. In: Proceedings 24th Asian-Pacific Weed Science Society Conference, October 2225, 2013, Bandung, Indonesia.

Khaliq, A., Matloob, A., Ahmed, N., Rasul, F. and Awan, I.U. Post emergence chemical weed control in direct seeded fine rice. $J$. Ani. Plant Sci., 2012, 22: 1101-1106.

Kumar, V and Ladha, J.K. Direct seeded of rice. Recent developments and future research needs. Adv. in Agronomy, 2011, 111:299413.

Kumar, V., Bellinder, R.R., Brainard, D.C., Malik, R.K. and Gupta, R.K. Risks of herbicide-resistant rice in India: A review. Crop prot., 2008, 27: 320-329.

Kumaran, S.T., Kathiresan, G., Murali, A.P., Chinnusamy, C. and Sanjivkumar, V. Efficacy of new herbicide (bispyribac sodium $10 \%$ SC) against different weed flora, nutrient uptake in rice and their residual effects on succeeding crop of green gram under zero tillage. J. Applied and Natural Sci., 2015, 7(1): 279 - 285.

Ladha, J.K., Dawe, D., Pathak, H., Padre, A.T., Yadav, R.L., Singh, B., Singh, Y., Singh, Y., Singh, P., Kundu, A.L., Sakal, R., Ram, N., Regmi, A.P., Gami, S.K., Bhandari, L., Amin, R., Yadav, C.R., Bhattarai, E.M., Das, S., Agrawal, H.P., Gupta, R.K. and Hobbs, P.R. How extensive are yield declines in long term rice-wheat experiments in Asia. Field crops Res., 2003, 81:159-180.

Mahajan, G. and Chauhan, B.S. Herbicide options for weed control in dry seeded aromatic rice in India. Weed Tech., 2013, 27: 682-689.

Mahajan, G., Chauhan, B. and Johnson, D. Weed management in aerobic rice in Northwestern Indo-Gangetic Plains. $J$. Crop Improv, 2009, 23: 366-382.

Maity, S.K. and Mukherjee, P.K. Integrated weed management practices in dry direct seeded summer rice. Indian J. Weed Sci., 2009, 79: 976-979.

Matloob, A., Khaliq, A. and Chauhan, B.S. 2015. Weeds of direct-seeded rice in asia: problems and opportunities. $A d v$. in Agronomy, 2015, 30: 291-335.

Mewada, P., Chaudhary, S.K., Rathore, A.K. and Singh, Y. Optimization of suitable weed management practices for aerobic rice. Indian J. Weed Sci., 2016, 48(1): 6466.

Mukhopadhyay, S.K. and Duary, B. 1999. Autecology of Ludwigia parviflora Roxb. - a predominant weed of Kharif rice in West Bengal, p.75. In: Proceedings of the Seventeenth Asian Pacific Weed Science Society Conference, 1999, Nov. 22-27, Bangkok.

Murali, P., Chinnusamy, C. and Prabhakaran, N.K. Early post emergence application of azimsulfuron on weed control and productivity of irrigated and rainfed direct seeded rice. Biennial conference of Indian society of weed science on Recent Advances in Weed Science Research2010, February 25-26, Indira Gandhi Krishi Vishwavidyalay, Raipur. p 56. 
Olofsdotter, M., Navarez, D.C. and Moody, K. Allelopathic potential in rice (Oryza sativa L.). Annals of Applied Bio., 1995, 127: 543-560.

Payman, G. and Singh, S. Effect of seed rate, spacing and herbicide use on weed management in direct seeded upland rice. Indian J. Weed Sci., 2008, 40: 11-15.

Prasuna, J.G. and Rammohan, J. Effect of weed management practices on growth and yield attributes of aerobic rice. J. Crop and Weed, 2015, 11(1): 229-231.

Raikar, S.D., Rajkumara, S. and Hanamaratti, N.G. Studies on chemical weed control in aerobic cultivated rice. Int. J. Plant Sci., 2009, 4(2): 334-337.

Raj, S.K., Jose, N., Mathew, R. and Leenakumary, S. Chemical management of non-grassy weeds in direct-seeded rice. Indian J. Weed Sci., 2013, 45(3): 159162.

Ramachandiran, K. and Balasubramanian, R. Efficacy of herbicides for weed control in aerobic rice. Indian J. Weed Sci., 2012, 44(2), 118-121.

Ranjit. Weeds associated with different crops. In: Paper Presented to Training on Weed Management in Rice, 2007, April 25-27, NARC, Khumaltar, Nepal.

Rao, A.N., Johnson, D.E., Sivaprasad, B., Ladha, J.K. and Mortimer, A.M. Weed management in direct-seeded rice. $A d v$. Agron., 2007, 93: 153-257.

Rao, A.S. and Ratnam, M. Evaluation of post emergence herbicides on weed control in rice nursery. Pak. J. Weed Sci. Res., 2010, 16: 387-392.

Rao, V. S. Principles of weed science, Oxford and IBH Publishing Co. Private Limited, New Delhi, 1986, pp 450.

Rawat, A., Chaudhary, C.S., Upadhyaya, V.B. and Jain, V. Efficacy of bispyribacsodium on weed flora and yield of drilled rice. Indian J. Weed Sci., 2012, 44(3): 183-185.

Rodenburg, J. and Demont, M. Potential of herbicide resistant rice technologies for sub-Saharan Africa. Ag. Bio. Forum, 2009, 12: 313-325.
Roder, W. Slash and burn rice systems in the hills of Northern Lao PDR. In: Description, challenges and opportunities IRRI, LOS Banos, Philippines, 2001, pp 201.

Saha, S. Efficacy of herbicides in wet direct sown summer rice. CRRI, Cuttack. Indian J. Weed Sci., 2006, 38: 45-48.

Sanches, P.A. Puddling tropical Soils, Effects on water losses. Soil Sci., 1973, 115: 303308.

Sanint, L.R., Correa-Victoria, F.J. and Izquierdo, J. The current situation and issues in rice production in Latin America and Caribbean. In: Proceedings of International Rice Conference. FAO, Rome, 1998, p. 35.

Sasikala, K., Boopathi S.N.M.R. and Ashok, P. Evaluation of methods of sowing and post emergence herbicides for efficient weed control in zero till sown rice fallow black gram (Vigna mungo [L]). Int. J. Farm Sci., 2014, 4(1): 81-91.

Singh, A., Singh, R.K., Kumar, P. and Singh, S. Growth, weed control and yield of directseeded rice as influenced by different herbicides. Indian J. Weed Sci., 2013, 45(4): 235- 238.

Singh, N.K. and Singh, U.P. Crop establishment methods and weed management on growth and yield of dry direct-seeded rice. Indian J. Weed Sci., 2014, 46(4): 308-313.

Singh, R., Ram Pal, Singh, T., Singh, A.P., Yadaw, S. and Singh, J. Management of weeds in direct-seeded rice by bispyribacsodium. Indian J. Weed Sci., 2009, 6(2): 126-128.

Singh, R., Ram Pal, Singh, T., Singh, A.P., Yadaw, S. and Singh, J. Management of weeds in direct-seeded rice by bispyribacsodium. Indian J. Weed Sci., 2014, 46(2): 126-128.

Singh, S., Bhusan, L., Ladha J.K., Gupta, R.K., Rao, A.N. and Sivprasad, B. Weed management in dry seeded rice (Oryza sativa) cultivated in the furrow-irrigated raised-bed planting system, 2005, www. elsevier.com/locate/cropo. 
Singh, S., Bhushan, L., Ladha, J.K., Gupta, R.K., Rao, A.N. and Sivaprasad, B. Weed management in dryseeded rice (Oryza sativa) cultivated on furrow irrigated raised bed planting system. Crop Prot., 2006a, 25: 487-495.

Singh, S., Sharma, R.K., Gupta, R.K. and Singh, S.S. Changes in rice-wheat production technologies and how rice wheat became a success story: Lessons from Zero-tillage wheat. In DirectSeeding of Rice and Wed management in the Integrated Rice-wheat Cropping System of the Indo-gangetic Plains (Y. Singh, V.P. Singh, B. Chauhan, A. Orr, A.M. Mortimer, D.E. Johnson, and B. Hardy, Eds.), 2008. PP 91-106. International Rice Research Institute, LOS Banos Philippines and Directorate of Experiment Station, G.B. Pant University of Agriculture and Technology, Pantnagar, India.

Singh, U.P. Singh, R.P. and Singh, Y. Integrated Weed Management in Direct Dry Seeded Rainfed Lowland Rice. Indian J. Weed Sci., 2006b, 38(I \& 2): 4953.

Singh, V.P. and Singh, G. Weed control studies in spring rice (Oryza sativa L.) under rainfed low valley situation of Uttaranchal. Indian J. Weed Sci., 2001, 33: 52-55.

Sreedevi, B., Krishnamurthy, P. and Singh, S.P. Nitrogen uptake and energy consumption of weeds in wet seeded rice. In: National symposium on weed threat to environment, biodiversity and agriculture productivity, TNAU, Coimbatore, 2009, P-49.

Sreedevi, B., Thakur, C. L., Senguttuvel, P., Sandhyarani, A., Dhanunjareddy, B., Kumar, R.M., and Ravindrababu, V. Energy dynamics of herbicidal weed control in aerobic rice. ICAR- Indian Institute of Rice Research- Newsletter, 2016, 14(1): 8-9.

Sunil, C.M., Shekara, B.G., Kalyanamurthy, K.N. and Shankaralingappa, B.C. Growth and yield of aerobic rice as influenced by integrated weed management practices. Indian J. Weed Sci., 2010, 42(3 \& 4): 180-183.

Upasani, R.R., Thakur, R. and Singh, M.K. Influence of sowing time and weed control methods on weed flora and productivity of direct seeded upland rice. Indian J. Weed Sci., 2010, 42(1\&2): 1416.

Walia, U.S., Walia, S.S. Sidhu, A.S. and Nayyar, S. Bioefficacy of pre- and postemergence herbicides in direct-seeded rice in Central Punjab. Indian J. Weed Sci., 2012, 44(1): 30-33.

Zhao, D.L., Atlin, G.N., Bastiaans, L. and Spiertz, J.H.J. Cultivar-weed competitiveness in aerobic rice: heritability, correlated traits, and the potential for indirect selection in weedfree environment. Crop Sci., 2006, 46: 372-380.

\section{How to cite this article:}

Chandu Lal Thakur, G.K. Shrivastava, B. Sreedevi and Thakur, A.K. 2018. Realising Aerobic Rice Potential in India - An Integrated Weed Management Perspective. Int.J.Curr.Microbiol.App.Sci. 7(02): 575-589. doi: https://doi.org/10.20546/ijcmas.2018.702.073 